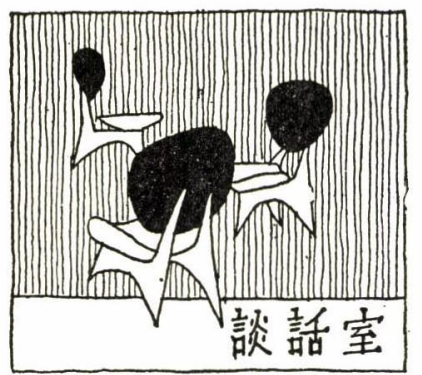

中性子トポグラフィの現状

\title{
富 満広*
}

\section{1.はじめに}

中性子の大きな物質透過能を利用した, Ge ブロック内の丕み場の観察 ${ }^{1)}$ (1971 年, 土井ほか; 1974年 富満・土井) や, 磁気感受性を利用した $\mathrm{Cr}$ 内の磁区の研究2) (1971 年, 細谷・安藤; 1972 年, 安藤・ 細谷) など，中性子回折トポグラフィが日本で創始されてから，まだ日は浅い，その後フフランスなど で,いくつかの仕事が行なわれている.

筆者は昨夏, 第10回国際結晶学会議（アムステルダム）および「X線動力学理論およびトポグラフィ に関する国際夏の学校」（リモージュ）に参加し，それらの中で中性子トポグラフィの現状を概観する 機会を得た。

国際会議では, Grenoble の Schlenker らのグループが二編の仕事を報告し， Saclay のグループが Si 中の転位像を高分解能の見事なトポグラフで展示して注目を惹き，筆者も高分解能のトポグラフを得る ためのモノクロ・試料結晶の配置に関する考察を発表した.

夏の学校では, Schlenker が中性子トポグラフィの原理から応用例を総合して講義した。

以下の報告では, 主にこれらの研究例を紹介する.

\section{Schlenker らの仕事}

Grenoble の Schlenker らのグループは, 1973 年以来, 中性子トポグラフィを用いた仕事をいくつか 発表している32 5).

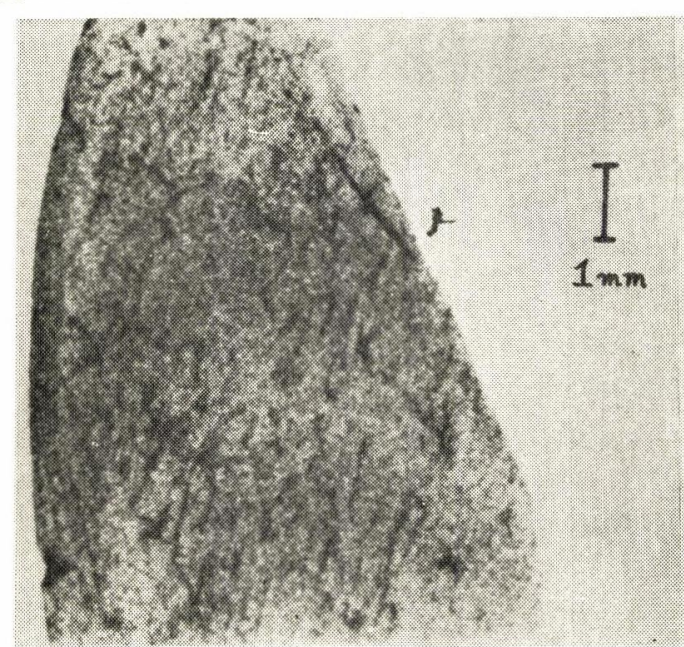

(a)

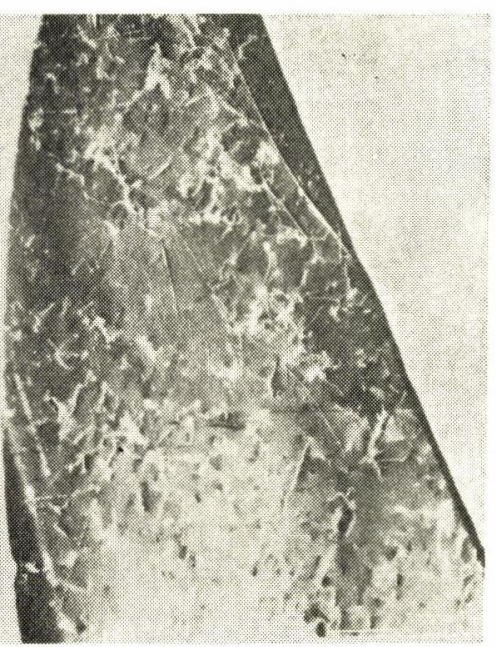

(b)

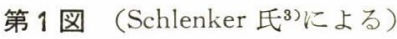

* 日本原子力研究所 固体物理第一研究室 


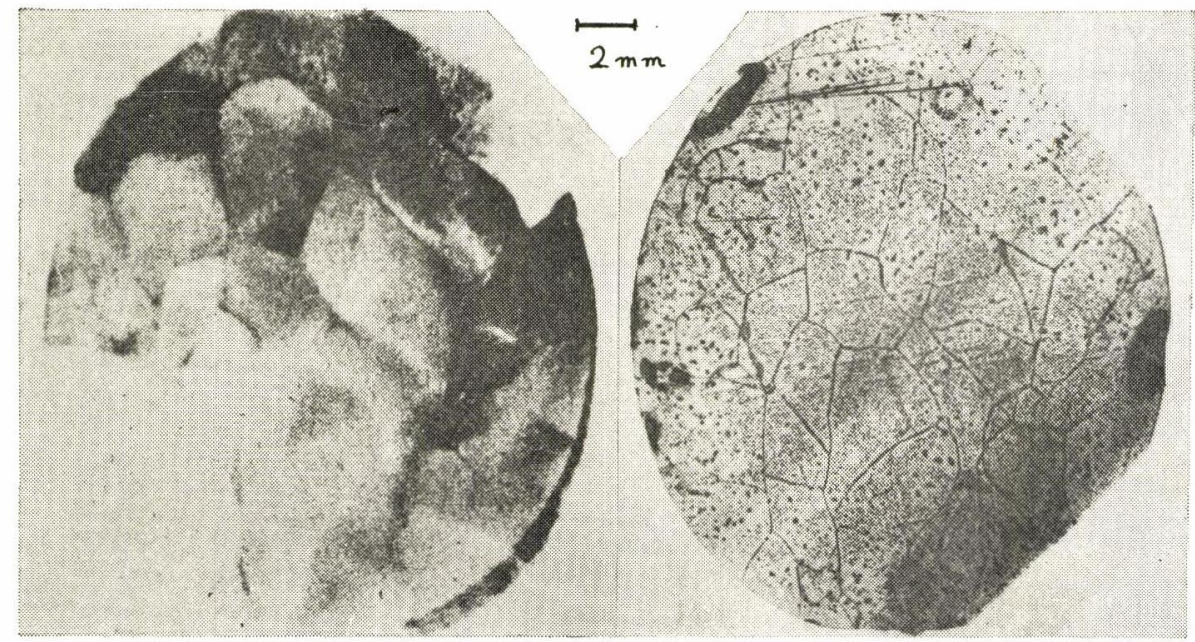

(a)

第 2 図 (Schlenker 氏4)による) (b)

彼らは, 中性子トポグラフィで初めて転位を見た ${ }^{3)}$. 第 1 図は, 厚さ $320 \mu \mathrm{m}$ の Si 板の中の転位像である. 中性子トポグラフ (a図) の黒い転位像 (Kinematical image)の1つ1つが, X線トポグラフ ( b 図)の白い 像 (dynamical image) に対応づけれるのがわかる.

第 2 図a）は，学会で彼が発表したセクション・ト ポグラフの興味深い応用例である4). 作製したままの 試料インゴット ( $\mathrm{Fe}-3 \% \mathrm{Si}$, 直径 $2 \mathrm{~cm})$ の中の subgrain が見事にとらえられている.なおb図は，この インゴットをスライスにして得られたX線トポグラフ である.

彼らはまた，“中性子ラウェ写真”ともいうべき技 法を用いた仕事を報告した5). 白色中性子線束の発散 角を抑えることにより分解能が上り，各ラウエ斑点の 中に sub-grain や inclusion の分布が観察された. こ れもまた, 試料結晶の様子を手軽に検査できる利点が ある・

これらの仕事はいずれも, ILL の高中性子束炉6)を 用いて行なわれ，各トポグラフはわずか数時間の露出 で得られている. 更に, ビームガイド方式で 2 分程度

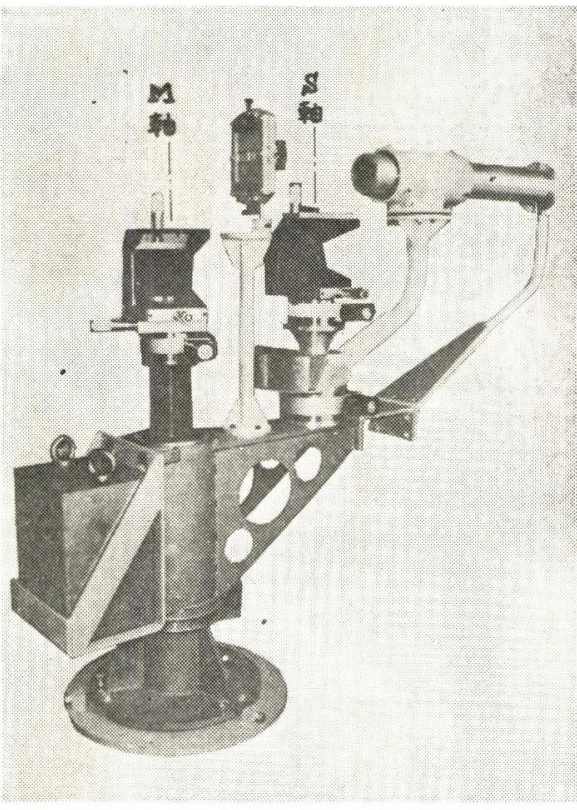

第3図 ILL 設置の中性子トポグラフィ装置 (Schlenker 氏の好意で筆者撮影) に発散角を抑えるこの “modern reactor” は, back ground を低減させ, 装置の様相をも一变させる. 第 3 図は, Schlenkerの設計になる中性子トポグラフィ装置であるが, 図中のM軸 (モノクロ結晶軸)と S 軸 (試料軸) の距離は $35 \mathrm{~cm}$ しかないといら程, 型破りにコンパクトにおさまっている.これは昨秋, ILL に設置されて稼動を開始しているはずである.

\section{Saclay グループの転位像}

この仕事は, Authier 門下の 3 人が Saclay の Englander と組えで行なったもので7), 学会のポスター セッセションで発表されたSi 中の転位像は, その像幅約 $30 \mu \mathrm{m}$, 現在最も鮮鋭な転位像である. この見

18. 1-42 
事なトポグラフは, 通常型の原子炉 (fluxは, ILLの 20 分の 1 である由)を用いて, 約 100 時間の露 出を要したという.

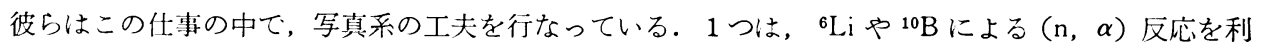
用して cellulose nitrateに記録する方法, 他は Gd の (n， $\beta$ ) 反応を用いて Kodak dental film に記録す る方法である．前者の方が，コントラストは低いが，より鮮鋭な転位像を示していると思われた。

この仕事の詳紐は, 近々論文発表されるといらから楽しみである.

\section{4. おわりに}

以上のように, 中性子トポグラフィは今や実用化の段階に入っているといえよう. 写真系その他の分 解能・像質向上の努力と併行して…… その際, ILL の例に見られるような modern な炉が, 露出時間 短縮・低ノイズといら独得の長所を発揮していることは，感心ばかりしてはおれない気がする．

なお箻者らも，第 4 図のごとき配置の専用装置を完成し，中性子トポグラフィの実用化に歩及出して いる。こ机は，モノクロ結晶で高角回折を，試料結晶で低角回折を行ならことにより結像線束の発散角 を抑兄，高分解能のトポグラフ撮影が可能である上ら配虑されている8

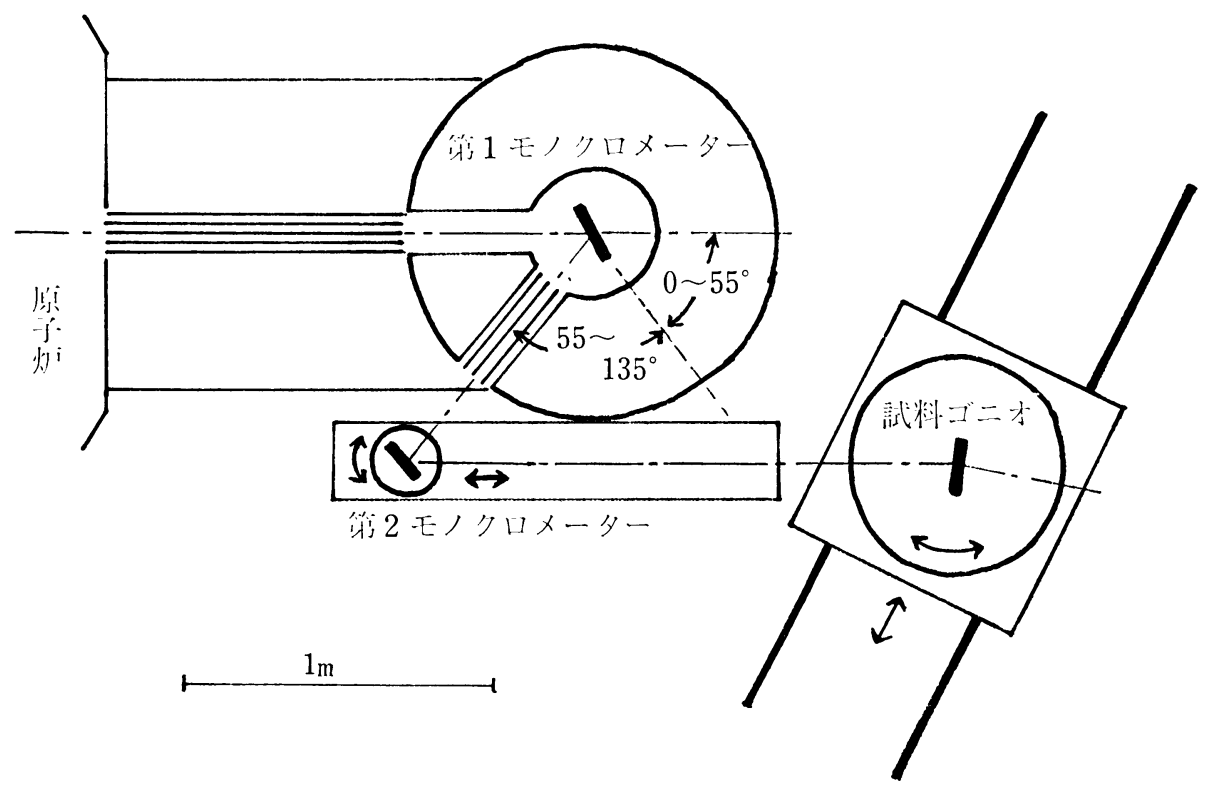

第 4 図原研 JRR-2 設置の中性子トポグラフィ装置

終わりに, Schlenker 氏が本報告のためにトポグラフのオリジナルコピーを快く提供され，また装置 の写真撮影を許容されたことに対し, 心からの謝意を表します。また, 筆者の滞欧中に, 種々の助言を 下さった諸先生方に深く感謝します. 本報告の原稿に目を通された土井博士に対しても謝意を表します.

\section{参考文献}

1) K. Doi, N. Minakawa, H. Motohashi \& N. Masaki : J. Appl. Cryst. 4, 548 (1971)

H. Tomimitsu \& K. Doi : J. Appl. Cryst. 7, 59 (1974)

2) S. Hosoya \& M. Ando : Phys. Rev. Lett. 26, 321 (1971)

M. Ando \& S. Hosoya : Phys. Rev. Lett. 29, 281 (1972)

3) M. Schlenker, J. Baruchel, J. P. Petroff \& W. B. Yelon : Appl. Phys. Lett. 25, 382 (1974)

4) M. Schlenker, J. Baruchel, R. Perrier de la Bathie \& S. A. Wilson : J. Appl. Phys. 46, 
2845 (1975)

5) A. Boeuf, S. Lagomarsino, F. Rustichelli, J. Baruchel \& M. Schlenker : to be published

6) 船橋 達: 日本物理学会誌 30,485 (1975)

7) M. Englander, C. Malgrange, J. F. Petroff \& M. Sauvage : the 10 th IUCr, Collected Abstracts, s. 243 (1975)

8) H. Tomimitsu : the 10 th IUCr, Collected Abstracts, s. 255 (1975)

※なお，中性子回折トポグラフィの概要に関しては下記を参照されたい，富満 広：日本結晶学 会誌 15，333 (1973). なお，この文献の中で，P. 333 の 4 行目後半から 5 行目前半まで「… …との強度は……比例する. 従って」の記述は不正確ですので, 削除する.

日本結晶学会誌 18,44 (1976)

ホジキン研究室

坂 部 知 平*

Oxford 市は11世紀以来のあら河る西洋建築を供えた大小悌々な college と町の建物が渾然一体となっ ている静かで美しい古風な町です，町の人達は古い物への憧憬が強く，伝統ある町の調和を損なら様な ものや急激な变化をあまり好みませんが，その様な oxford の町にも最近次第に近代的ビルディングが 建つ様になりました，その一つが Department of Zoology で，その白い大きな建物は能率良く研究活動 ができる様工夫され，余裕ある広さ艺持っており，裏手には芝生の敷き詰められた大きなクリケットと サッカー場が広がっております。

Hodgkin 研究空はこの建物の 2 階にあり，多くの国々から研究者が集って来ていました．私澾は1973 年 5 月より 1975 年 3 月まで Hodgkin 研究室に留学する機会を得ましたが，当時英国人は Dorothy Hobgkin 教授と M. Adams 博士の 2 人だけで, 多忙な Hodgkin 先生を助けていたのはカナダ人の秘書 D. Brzezicki さんと研究室のマネジャ一役をしているニュージーランド人の G. Dodson 博士で, この他 はオーストラリヤ人, アメリカ人, ドイッ人, フランス人, チェコスロバキャ人, スイス人, インド人 それに私達日本人といった具合でした，数年前には中国人も来ていたそうです. 平均 25 名程度の postdoctral がいたそらですが，Hodgkin 先生は定年退職が近いため人数を減らしておられ，私達が州国す る頃にはすでに postdoctral が私详を含めて 8 人，大学卒 3 名になっていました。

Hodgkin 先生は大変庶民的な方で, 気楽に誰とでも話をされ，細い点まで気を配って下さいます，例 えば私達が Oxfordに着いた日，家が定まるまで泊るため予約しておいていただいた Halifax house に 先生自身が私達を案内して下さいました， 夕食を先生と共にしたのですが，その時 London で翌日から 3 日間生体膜についての公演会があるが聴きに行かないかといわれ, 朝が早いからといってタクシーの 予約をして下さったり，また着いたばかりで小銭を持っていないのではないか等細かい所まで心を配っ て下さったりして，全く恐縮した記憶があります，先生はフーリエ図を御覧になるのが特にお好きで， 時には楽しそうに口笛を吹きながら何時までも見入っておられることがありました．週末には夫君の住 んでおられる cottage 風の大きな，かつては親族の方 4 家族が住んでいたというエルミントンへ㷌宅さ れますが, 普通の日は研究室から歩いて15 分程度の所に住んでおられ, 夕食後も研究室に戻られ，夜 おそくまで仕事をされていました。でも国際結晶学会会長をはじめ数多くの重要な仕事をしておられま すので大変打忙しく，特に夏から秋にかけては，あまりお姿はみられませんでした。

Hodgkin 研究室では主として Insulin の研究を行なっていました。特に2Zn-Insulin は多角的に研究

* 名古屋大学理学部

18. 1-44 